\title{
RADIOPACITY OF RESTORATIVE MATERIALS USING DIGITAL IMAGES
}

\author{
RADIOPACIDADE DE MATERIAIS RESTAURADORES UTILIZANDO IMAGENS DIGITAIS
}

Leda Maria Pescinini SALZEDAS', Mário Jefferson Quirino LOUZADA², Antonio Braz de OLIVEIRA FILHO ${ }^{3}$

1- DDS. MSc, PhD, Assistant Professor, Department of Pathology, Araçatuba Dental School, UNESP, São Paulo State University.

2- DDS. MSc, PhD, Assistant Professor, Department of Production and Health animal, Araçatuba Dental School, UNESP, São Paulo State University.

3- DDS, Graduate student, Recipient of CNPq scholarship, Araçatuba Dental School, UNESP, São Paulo State University.

Corresponding address: Dra . Leda Maria Pescinini Salzedas - UNESP, Faculdade de Odontologia de Araçatuba - Rua José Bonifácio, 1193 Vila Mendonça-Araçatuba-São Paulo-Brasil - Cep.:16015-050 - Telefone: (18) 3636-3310 - Fax: (18) 3636-3340 - e-mail: ledamps@foa.unesp.br

Received: July 5, 2005 - Modification: October 07, 2005 - Accepted: December 22, 2005

\begin{abstract}
7

he radiopacity of esthetic restorative materials has been established as an important requirement, improving the radiographic diagnosis. The aim of this study was to evaluate the radiopacity of six restorative materials using a direct digital image system, comparing them to the dental tissues (enamel-dentin), expressed as equivalent thickness of aluminum (millimeters of aluminum). Five specimens of each material were made. Three 2-mm thick longitudinal sections were cut from an intact extracted permanent molar tooth (including enamel and dentin). An aluminum step wedge with 9 steps was used. The samples of different materials were placed on a phosphor plate together with a tooth section, aluminum step wedge and metal code letter, and were exposed using a dental x-ray unit. Five measurements of radiographic density were obtained from each image of each item assessed (restorative material, enamel, dentin, each step of the aluminum step wedge) and the mean of these values was calculated. Radiopacity values were subsequently calculated as equivalents of aluminum thickness. Analysis of variance (ANOVA) indicated significant differences in radiopacity values among the materials $(\mathrm{P}<0.0001)$. The radiopacity values of the restorative materials evaluated were, in decreasing order: TPH, F2000, Synergy, Prisma Flow, Degufill, Luxat. Only Luxat had significantly lower radiopacity values than dentin. One material (Degufill) had similar radiopacity values to enamel and four (TPH, F2000, Synergy and Prisma Flow) had significantly higher radiopacity values than enamel. In conclusion, to assess the adequacy of posterior composite restorations it is important that the restorative material to be used has enough radiopacity, in order to be easily distinguished from the tooth structure in the radiographic image. Knowledge on the radiopacity of different materials helps professionals to select the most suitable material, along with other properties such as biocompatibility, adhesion and esthetic.

Uniterms: Densitometry; Dental material; Digital radiography.
\end{abstract}

\section{RESUMO}

A radiopacidade dos materiais tem sido valorizada como importante requisito, incrementando o diagnóstico radiográfico. O objetivo deste estudo foi avaliar, no sistema digital Digora, as densidades radiográficas de 06 materiais restauradores comparando-os aos tecidos dentais (esmalte e dentina), expressos em milímetros de alumínio (mm Al). Foram confeccionadas 05 amostras de cada material e três cortes de um molar extraído hígido (incluindo esmalte e dentina), com 2 mm de espessura, e um penetrômetro de alumínio com 09 degraus. Sobre cada placa óptica foram colocados amostras dos diferentes materiais, um corte do dente humano, o penetrômetro e a identificação, e feita a exposição utilizando um aparelho de raios X. Foram obtidas 05 medidas de densidade radiográfica de cada item avaliado (material restaurador, esmalte, dentina e degraus do penetrômetro de alumínio) em cada radiografia, e calculadas as médias destas medidas. A partir destas médias de densidade, foram calculados os valores da radiopacidade destes itens em mm de Al, em cada radiografia. Análise de variância (ANOVA) indicou diferença significante entre os valores de radiopacidade dos materiais $(\mathrm{p}<0.0001)$. A radiopacidade dos materiais restauradores avaliados foi em ordem decrescente: TPH, F2000, Synergy, Prisma Flow, Degufill, Luxat. Apenas o Luxat apresentou radiopacidade inferior ao esmalte e dentina. Um material não diferiu estatisticamente do esmalte (Degufill) e quatro apresentaram radiopacidade superior ao esmalte (TPH, F2000, Synergy, Prisma Flow). Portanto, faz-se necessária a avaliação de materiais restauradores disponíveis no mercado, proporcionando aos profissionais informações adicionais sobre os materiais restauradores que eles utilizarão.

Unitermos: Densitometria; Materiais dentários; Radiografia digital. 


\section{INTRODUCTION}

The success of a restorative material is directly related to its biocompatibility, along with its adhesive and esthetic properties $^{17}$. The use of posterior resin composite restorations has substantially increased over the past years. This is due to improvements in dental materials and mainly to patients' demand regarding esthetic restorations ${ }^{16,20}$.

The radiopacity of restorative materials has been established as an important requirement because it regulates the material reflection degree, allowing a proper contrast from the tooth structure on a radiograph. Adequate radiopacity permits assessment of marginal overhangs, open gingival margins, interproximal contour as well as recurrent caries in the gingival areas ${ }^{1,15,18,20,21}$. Thus, the Council on Dental materials, Instruments and Equipments ${ }^{3}$ revised the requirements for resin-based restorative materials and the radiopacity was added to the biological, physical and mechanical requirements.

Tveit and Espelid ${ }^{22}$ verified in 1986 that most of the available commercially composite resins had lower radiopacity than the hard dental tissues. The first glass ionomer cements were radiolucent, providing limitation in its use as a restorative material. Recently, flowable composite, compomer and chemical-cured composites have been advocated to reduce the adverse effects of polymerization shrinkage. Compomers are acid-modified composite resins whose mechanical properties assert to be similar to the glass ionomer cements ${ }^{17}$, with the advantage of presenting higher radiopacity, as shown in the literature ${ }^{4,17}$.

The radiopacity of glass ionomer-based dental materials is totally variable $\mathrm{e}^{15,16,18,19}$ and their radiopacity may be sufficient to use them as a base or liner material. The use of less radiopaque materials than dentin as a base under restorative materials could be radiographically mistaken for decalcified or carious dentin ${ }^{15}$.

Moderately radiopaque materials are preferable to those with a high degree of radiopacity, since the latter may obscure caries adjacent to restorations ${ }^{6,8,22}$. It is desirable that restorative materials have radiopacity values similar to or higher than that of enamel for better performance $e^{6,19,20}$. Requirements for the radiopacity of dental restorative resin established by Organization for Standards (ISO/DP 4049) ${ }^{11}$ specifies that the radiopacity of a 2-mm thick specimen of the material should be equal to that of a $2 \mathrm{~mm}$ or larger thickness of aluminum ${ }^{8}$. One of the techniques used to evaluate radiopacity of dental materials has been comparing specific thickness of composite to aluminum step wedges under controlled radiographic conditions. The radiopacity of a dental material specimen is usually expressed in terms of equivalent aluminum thickness (in millimeters) using a reference calibration curve $e^{5,15,25}$.

Studies corcerning the relative radiopacity (aluminum equivalent value) of different restorative materials showed considerable variation in radiopacity values among the materials tested ${ }^{4,9,14,25}$. The restorative materials displayed similar or greater radiopacity than enamel, radiopacity values varied between dentin and enamel radiopacity, and the values were similar to dentin radiopacity. The digital image has appeared like a fast and easily evaluated resource, and has been widely used in dental practice, with the possibility of being obtained through direct or indirect methods according to a specific computer program. ${ }^{10}$ The use of digital radiograph is very flexible, as it is shown by Vulcano, et al. ${ }^{27}$ who developed a study by using a optical densitometry technique in order to determine bone density of the ulnar carpo of growing equines, aiming at standardizing the normal values of bone density.

The advantages of direct digital systems are immediate image capture and avoidance of processing chemicals, their wide dynamic range and increased sensitivity to radiation exposure $^{24}$. The Digora digital system (stimulable phosphor plate) has proven to be safe, fast and user-friendly for radiopacity evaluation ${ }^{7,24}$.

It has been the aim of this study to evaluate the radiopacity of some restorative materials using a storage phosphor plate and compare the radiopacity values to those of enamel and dentin, expressed as equivalent thickness of aluminum.

\section{MATERIALS AND METHODS}

The six materials evaluated in this study are listed in Table 1.

Five standardized specimens of each material were made, according to the manufacturers' instructions. The materials were placed with a syringe (Centrix, 3M Dental Products St Paul, MN, USA), in the 2-mm deep and 6-mm internal diameter plastic rings, interplaced between two microscopic glass

TABLE 1- Restorative materials and manufacturers used in this study

\begin{tabular}{lll}
\hline MATERIAL & PRODUCT & MANUFACTURER
\end{tabular}

Light-cured micro-hybrid composite resin

Light-cured micro-hybrid composite resin

Light-cured hybrid composite resin

Liht-cured compomer

Light-cured fluid compomer

Light-cured restorative compomer

Degufill Mineral
Synergy
TPH
Luxat
Prisma Flow
F2000

Degussa-Germany

Coltene-Switzerland

Caulk/Dentsply-USA

DMG Hamburg

DMG Hamburg-Germany

3M Dental Products- USA 
slide and pressed, to allow for a smooth surface and no gap formation. After trimming the excess from all restorative materials, each specimen was placed with fine and super fine discs (Sof-lex, 3M, Brazil). The specimens were stored under moist conditions at $37^{\circ} \mathrm{C}$ until the radiographic part of the experiment was conducted.

Three 2-mm thick longitudinal sections of enamel and dentin were cut from extracted human molar tooth with a low-speed diamond saw. These specimens were stored in water until the moment of use.

A nine-step aluminum step wedge (6063 alloy, ABNT) was used to correlate the density of images of specimens to that of aluminum, allowing to check accordance with the International Standard Organization (ISO/DP 4049) ${ }^{11}$ requirements for resin-based material radiopacity.

The dental x-ray unit (GE-100, General Electric, Milwaukee, USA) was set at $50 \mathrm{Kvp}, 10 \mathrm{~mA}, 12$ impulses, with a focus-film distance of $30 \mathrm{~cm}$. The direct digital image was obtained with a storage phosphor plate as the image receptor (Digora, Soredex, Orion Corporation, Helsinki, Finland). Three specimens of different materials, one tooth section, aluminum stepwedge and metal code letter/number were placed on the phosphor plate. The phosphor plate was scanned in the dedicated Digora scanner, and image was displayed on the PC monitor.

The Digora sotware for Windowns, version 1.51, automatically calculated the mean grey shade values in the areas which were drawn with a mouse directly on the images, on the monitor. A digital image consists of pixels (picture elements) which are aligned in rows and columns constituting the matrix of images. Pixel areas were standardized in order to be used in each one of the items analyzed (enamel-12x12, dentin and specimens of materials30x30, and aluminum stepwedge-26x92). The program presents the highest and the lowest grey shade available in the area which were draw. We use the mean grey shade value (automatically calculated by program) only for the calculations required (Figure 1 ).

Five readings of density values were obtained from each item, on each image, and the arithmetic mean of these

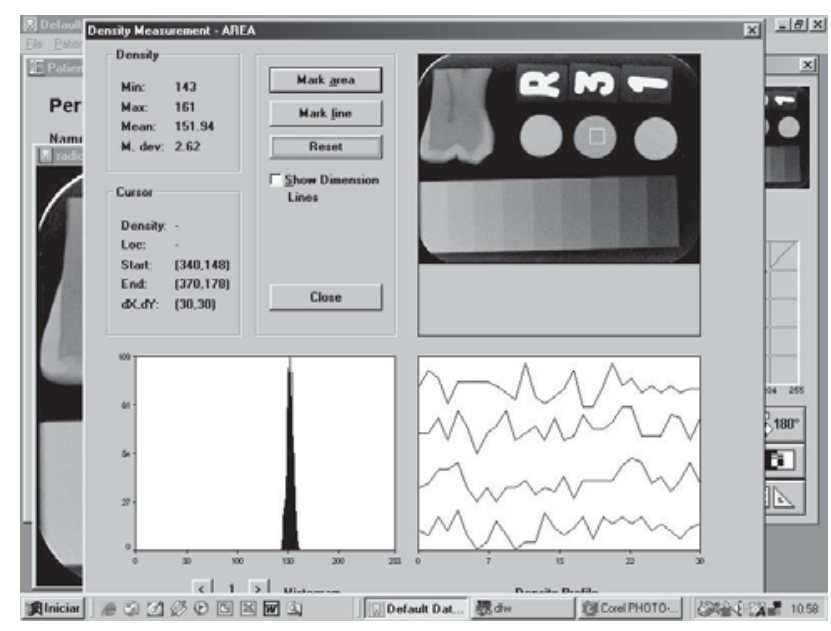

FIGURE 1- Determination of density value of materials using the Digora software repetitions calculated, corresponding to the density value of the item. The density of stepwedge steps was measured and a graph of radiographic density versus the thickness of aluminum at each step was constructed. The graph was used to calculate the aluminum equivalency values for the mean radiographic density readings of each material specimen as well as those enamel and dentin. The equation from the curve of each item was obtained from the 3 values of the graph (linear regression): the radiopacity value of the step of the stepwedge closer to the radiopacity of the item, the step above and the step below. It is relevant to point out that a graph was made for each image, because the radiopacity of steps varies among images.

In the case of enamel and dentin, the radiographic density value was obtained by using 5 different images of each of the 3 tooth sections, and 5 readings of density values were made for each image, so that the arithmetic mean was obtained and converted into mmAl. The final radiopacity value for enamel and dentin was the mean of 15 values in mmAl (5 out of each tooth section).

The radiopacity values expressed in mmAl were statistically analyzed. Firstly, analysis of variance (ANOVA) with data transformed in log, post hoc Tukey's test to compare the groups. After this analysis, the means of radiopacity per group were compared with the means of radiopacity for enamel and dentin (the means' test was applied).

\section{RESULTS}

The radiopacity values varied among the restorative materials $(\mathrm{p}<0.0001)$ (Table 2$)$. As seen in Table 3 , TPH and F2000 were similar, Prisma Flow did not differ from Synergy and Degufill, and Luxat differed from all others.

The final density values of restorative materials investigated expressed as equivalents of aluminum thickness are given in Table 3 . The radiopacity values of restorative materials investigated were, in decreasing order: TPH, F2000, Synergy, Prisma Flow, Degufill, Luxat. Among all materials tested, only Luxat showed lower radiopacity than the same thickness (2mm) of aluminum.

Enamel showed a density equivalent to $4.19( \pm 0.008)$ $\mathrm{mmAl}$ and dentin equivalent to $2.57( \pm 0.0004) \mathrm{mmAl}$. Among all materials tested (Table 4), only Luxat was less radiopaque than enamel and dentin. The TPH, F2000, Synergy and Prisma Flow materials were more radiopaque than enamel. One material (Degufill) showed radiopacity similar to enamel.

\section{DISCUSSION}

In this study, we used digital image analysis that has been considered of the same accuracy than transmission densitometry, providing precise and trustworthy numerical values $^{7,10}$. In transmission densitometry we obtain optical density, which is a logarithmic measure of the ratio of transmitted to incident light through the film image, while in 
digital image analysis we have radiographic density directly, because the pixels already have their determined grey shades, directly providing the values at a scale 0 to 255, through the program ${ }^{7}$. Gürdahl and Akdeniz ${ }^{10}$, when comparing the efficacy of conventional radiometry with indirect digital image in the assessment of the radiopacity of restorative materials showed similar results. Direct digital image would still reduce the loss of information that should occur with the use of indirect digital image. The radiopacity of dental filling materials were evaluated by Wenzel, et al. ${ }^{24}$ using conventional intraoral radiographic film and two digital systems with the purpose to investigate the possibility of discrimination solely on the basis of radiopacity of materials.
The digital systems were less reliable than film in this discrimination. Ferreira, et al. ${ }^{7}$, when evaluating the radiopacity of endodontic materials, established from their results that Digora digital system is safe, fast and userfriendly for radiopacity evaluation.

Radiopacity of restorative materials has been considered an important requirement of restorative materials because it regulates the reflection degree of the material and light penetration variation, which are critical indicators of color quality of the material ${ }^{17}$. Radiopacity allows a proper constrast between enamel/dentin and restorative material, improving the radiographic diagnosis of recurrent caries, faulty proximal contour, and marginal adaptation ${ }^{1,6}$.

TABLE 2- ANOVA with data transformed in log

\begin{tabular}{llllll}
\hline source & DF & Sum of squares & Mean square & F value & p \\
\hline Group & 5 & 4.21270028 & 0.84294006 & 407.14 & $0.0001^{*}$ \\
Repetition & 4 & 0.00607995 & 0.00151999 & 0.73 & 0.5794 \\
Error & 20 & 0.04140738 & 0.00207037 & & \\
Total & 29 & 4.26218761 & & & \\
\hline
\end{tabular}

*Statistically significant difference

TABLE 3- Density values of restorative materials expressed as equivalent of aluminum thickness (mmAl). Tukey's test to compare the results among the groups

\begin{tabular}{llcl}
\hline Materials & N & Density means- mmAl & Group*(Tukey) \\
\hline TPH & 5 & $6,24 \pm 0,28$ & A \\
F2000 & 5 & $5,92 \pm 0,15$ & A \\
Synergy & 5 & $4,77 \pm 0,23$ & B \\
Prisma Flow & 5 & $4,51 \pm 0,24$ & B C \\
Degufill & 5 & $4,33 \pm 0,21$ & $\mathrm{C}$ \\
Luxat & 5 & $1,99 \pm 0,07$ & $\mathrm{D}$ \\
\hline
\end{tabular}

* Groups with the same letter are not significantly different. $p<0.05$

TABLE 4- Density values of restorative materials expressed as equivalent of aluminum thickness (mmAl). Comparison results among the groups and regarding enamel and dentin

\begin{tabular}{|c|c|c|c|c|c|}
\hline \multirow[t]{2}{*}{ Materials } & \multirow[t]{2}{*}{ Density means - mmAl } & \multicolumn{2}{|c|}{$\begin{array}{l}\text { Enamel } 4.19( \pm 0.008) \\
n=15\end{array}$} & \multicolumn{2}{|c|}{$\begin{array}{c}\text { Dentin } 2.57( \pm 0.0004) \\
n=15\end{array}$} \\
\hline & & F & $p$ & $F$ & $\mathbf{p}$ \\
\hline $\mathrm{TPH}$ & $6.24 \pm 0.28$ & 175.62 & $<0.0001^{*}$ & 934.0 & $<0.0001^{*}$ \\
\hline F2000 & $5.92 \pm 0.15$ & 144.68 & $<0.0001^{*}$ & 998.37 & $<0.0001^{*}$ \\
\hline Synergy & $4.77 \pm 0.23$ & 15.07 & $<0.0008^{*}$ & 374.65 & $<0.0001^{*}$ \\
\hline Prisma Flow & $4.51 \pm 0.24$ & 4.66 & $0.042^{*}$ & 285.87 & $<0.0001^{*}$ \\
\hline Degufill & $4.33 \pm 0.21$ & 1.04 & 0.3186 & 248.05 & $<0.0001^{*}$ \\
\hline Luxat & $1.99 \pm 0.07$ & 25.69 & $<0.0001^{*}$ & 32.89 & $<0.0001^{*}$ \\
\hline
\end{tabular}

* Statistical difference at significance level of $5 \%$ 
Radiopacity has also been valued in base materials and resinbased cements, in view of the increasing use of esthetic restorations. It is essential that resin cements and base materials be sufficiently radiopaque to allow detection of cement margin overhangs and under restorations ${ }^{9,15,16,18}$. It has been proposed that the radiopacity of restorative materials should be evaluated by using comparison with the radiopacity of the same thickness of enamel and dentin, and with an aluminum stepwedge as internal standard ${ }^{5,15,25}$. The relative radiopacities of materials, enamel and dentin are expressed as aluminum equivalent values, in millimeters. In this study, these parameters were utilized with the methodology proposed by Louzada, et al. ${ }^{13}$ with sectorization of calibration curve of each image. The mathematical expression represents the relation between the values of radiographic density of standard stepwedge's steps, and the thickness of aluminum. Any other object simultaneously radiographed have its measure density referenced in equivalent thickness of aluminum ${ }^{13}$. Louzada, et al. ${ }^{12}$ demonstrated the practicity, accuracy and sensitivity of the methodology in the evaluation of bone mass variation in dogs.

The radiopacity of the restorative material must be in accordance with the ISO Standard $4049^{11}$, being at least as radiopaque as the same thickness of dentin, which is the acceptable inferior limit of radiopacity. Even though the superior limit has not been established, some authors consider that it should exist, because very radiopaque materials, such as amalgam, impair radiographic identification of marginal adaptation, recurrent caries and other defects ${ }^{6,8,23}$ . ISO/DP $4049^{11}$ and other authors ${ }^{8}$ consider that the restorative material should present at least radiopacity equivalent to the same thickness of aluminum in order to allow diagnostic identification and it is important to use dental tissue cuts as a secondary standard ${ }^{23}$.

In the experimental conditions of this study, the radiopacity values of materials, in decreasing order, were: TPH, F2000, Synergy, Prisma Flow, Degufill, Luxat. This variability in the radiopacity of restorative materials are confirmed by others ${ }^{5,15,16,19}$. Radiopacity varies depending on the radiopaque component added to confer this property, such as silver alloy, zync, strontium, barium ${ }^{15,19}$ and quantity of particles filler. ${ }^{16}$ We verified that five of the six materials evaluated had higher radiopacity values than dentin (complied with the ISO Standard 4049) ${ }^{11}$. Only Luxat compomer had statistically different and lower radiopacity values than dentin.

If the material presents radiopacity similar or lower than dentin, recognition of the faulty proximal contour is impaired, as well as the diagnosis of secondary caries and other defects that lead to clinical failure ${ }^{14,20}$. However, while higher radiopacity values than dentin meet the ISO Standard 4049, ${ }^{11}$ several studies have indicated that the radiopacity of restorative materials should be similar to or slightly greater than enamel $\mathrm{l}^{4,5,6,9,15,19,20,22}$.

When evaluating the radiopacity of materials compared with the radiopacity of enamel, four of them (TPH, F2000, Synergy, Prisma Flow) had superior radiopacity. In accordance with these results, Bouschlicher, Cobb, Boyer ${ }^{4}$ showed that TPH was more radiopaque than enamel. One material (Degufill) had similar radiopacity to enamel and Luxat was less radiopaque than enamel. Differently from this study, which found a compomer that did not meet the criteria, Santos, et al. ${ }^{17}$ and Bouschlicher, Cobb, Boyer ${ }^{4}$, when evaluating compomers noticed that all of them were at least as radiopaque as dentin and complied with ISO Standard 4049. The compomers present the advantage of presenting higher radiopacity. The glass ionomer, as demonstrated by Akerboom, et al. ${ }^{2}$, have lower radiopacity than dentin and aluminum.

Thus, if we consider "acceptable radiopacity” defined as equal or higher than enamel, only Luxat did not meet this criteria, so its use for class II restorations may interfere with the diagnosis of recurrent caries.

When we compare the radiopacity of all materials (Table 3 ), we observe statistically similar radiopacity values to TPH and F2000. The Prisma Flow material did not differ from Synergy and Degufill, however, Synergy and Degufil were different from each other. Luxat differed from all the others.

In conclusion, to assess the adequacy of posterior composite restorations at baseline and recall examination, it is important that the restorative material to be used has enough radiopacity, in order to be easily distinguished from tooth structure in the radiographic image. Knowledge on the radiopacity of different materials helps professionals to select the most suitable material, along with other properties such as biocompatibility, adhesion and esthetic.

\section{ACKNOWLEDGEMENTS}

This investigation was supported in part by PIBIC/CNPq Program.

To Dr. Maria Lúcia Marçal Mazza Sundfeld for the statistic analysis.

\section{REFERENCES}

1. Aguiar CM, Varandas ET, Asfora KK, Santos MCMS, Becerra SRS, Silva RB. Diagnóstico da cárie dental. Rev Odontol Univ Santo Amaro. 1998;3:29-31.

2. Akerboom HBM, Kreule NCM, Van Amerogen WE. Radiopacity of posterior composite resin, composite resin liting material, and ionomer lining cements. J Prosthetic Dent. 1993;70:351-5.

3. American National Standard/ American Dental Asssociation (ANSI/ ADA) Specification $n^{0} 27$ for resin-based filling materials. Revision of ANSI/ADA Specification $n^{0}$ 27-1977. American Dent. Assoc.,1993: 226.

4. Bouschlicher MR, Cobb DS, Boyer DB. Radiopacity of compomers, flowable and conventional resin composites for posterior restorations.Oper Dent. 1999;24: 20-5.

5. Cook, WD. An investigation of the radiopacity of composite restorative materials. Aust Dent J. 1981;26:105-112. 
6. Espelid I, Tveit AB, Ericksson RL, Keck SC, Glasspoole EA. Radiopacity of restorations and detection of secondary caries. Dent Mater. 1991;7:114-7.

7. Ferreira FBA, Silva e Souza PAR, Vale MS, Tavano O. Radiopacidade de cimentos endodônticos avaliados pelo sistema de radiografia digital. Rev Fac Odontologia Bauru. 1999;7:55-60.

8. Goshima T, Goshima Y. The optimum level of radiopacity of composite inlay materials and cements. Oral Surg Oral Med Oral Pathol.1989;18:19-21.

9. Goshima T, Goshima Y. Optimum radiopacity of composite inlay materials and cements. Oral Surg Oral Med Oral Pathol. 1991;72:25760

10. Gürdal P, Akdeniz BG. Comparison of two methods for radiometric evaluation of resin-based restorative materials. Dentomaxillofac Radiol. 1998;27:236-9.

11. International Organization For Standardization. ISO Standard 4049: Dental resin-based restorative materials. International Standard Organization; 1985. cláusula 6.10.

12. Louzada MJQ, Pelá CA, Belangero WD, Santos-Pinto R. Avaliação da densidade óssea em imagens radiográficas: estudo em peças ósseas de cães. Rev Bras Eng/Caderno de Eng Biom. 1998;14:47-64.

13. Louzada MJQ, Pelá CA, Belangero WD, Santos-Pinto R. Metodologia para a avaliação de densidade em imagens radiográficas. Rev Bras Eng/Caderno de Eng Biom. 1998;14:37-47.

14. Murchison DF, Charlton DG, Moore WS. Comparative radiopacity of flowable resin composites. Quintessence Int. 1999;30:179-84.

15. Prévost AP, Forest D, Tanguay R, DeGrandmont P. Radiopacity of glass ionomer dental materials. Oral Surg Oral Med Oral Pathol. 1990;70:231-5.

16. Rubo MHM, El-Mowafy O. Radiopacity of dual-cured and chemical-cured resin-based cements. Int J Prosthodont. 1998;11:70-

17. Santos MCMS, Aguiar CM, Khoury H, Braz R. Avaliação das radiopacidades dos compômeros. Rev Odontol Univ Santo Amaro. 1999;40:22-5.

18. Shah PMM, Sidhu SK, Chong BS, Pitt Ford TR. Radiopacity of resin-modified glass ionomer liners and bases. J Prosthet Dent. 1997; 77:239-242.

19. Sidhu SK, Shah PMM, Chong BS, Pitt Ford TR.. Radiopacity of resin-modified glass-ionomer restorative cements. Quintessence Int 1996;27:639-43.

20. Silva RCSP, Araújo MAM, Giachetti NJ. Radiopacidade. Comparação entre resina composta, esmalte, dentina e amálgama. Odonto. 1992;2:272-6.

21. Tamburús JR. Radiopacidade de resinas compostas. Rev Odontol USP. $1990 ; 4: 103-7$.

22. Tveit AB, Espelid I. Radiographic diagnosis of caries marginal defects in connection with radiopaque composite fillings. Dent Mater. 1986;2:159-62.

23. Watts DC, Mccabe JF. Aluminium radiopacity standards for dentistry: an international survey. J Dent. 1999;7:73-8.

24. Wenzel A, Hintze H, Horsted-Bindslev P. Discrimination between restorative dental materials by their radiopacity measured in film radiographs and digital images. J. Forensic Odontostomatol. 1998; $16: 8-13$
25. Williams JA, Billington RW. A new technique for measuring the radiopacity of natural tooth substance and restorative materials. J Oral Rehabil. 1987;14:267-9.

27. Vulcano LC, Ciarlini LDRP, Louzada MJQ, Caldas ELC. Valores normais da densidade óssea do carpo ulnar em potros em crescimento da raça Quarto de Milha através da densidade óptica radiográfica. Hora Veterinária. 1997;17:52-4. 